NASA/TM-2000-209925

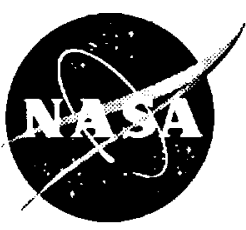

\title{
The Effect of Stress and TiC Coated Balls on Lifetime of a Perfluoropolyalkylether Using a Vacuum Rolling Contact Tribometer
}

William R. Jones, Jr., and Stephen V. Pepper

Glenn Research Center, Cleveland, Ohio

Mark J. Jansen and QuynhGiao Nguyen

AYT Corporation, Brook Park, Ohio

Donald R. Wheeler

Glenn Research Center, Cleveland, Ohio

Achim Schröer

Centre Suisse d'Electronique et de Microtechnique SA, Neuchatel, Switzerland 
The NASA STI Program Office . . . in Profile

Since its founding, NASA has been dedicated to the advancement of aeronautics and space science. The NASA Scientific and Technical Information (STI) Program Office plays a key part in helping NASA maintain this important role.

The NASA STI Program Office is operated by Langley Research Center, the Lead Center for NASA's scientific and technical information. The NASA STI Program Office provides access to the NASA STI Database, the largest collection of aeronautical and space science STI in the world. The Program Office is also NASA's institutional mechanism for disseminating the results of its research and development activities. These results are published by NASA in the NASA STI Report Series, which includes the following report types:

- TECHNICAL PUBLICATION. Reports of completed research or a major significant phase of research that present the results of NASA programs and include extensive data or theoretical analysis. Includes compilations of significant scientific and technical data and information deemed to be of continuing reference value. NASA's counterpart of peerreviewed formal professional papers but has less stringent limitations on manuscript length and extent of graphic presentations.

- TECHNICAL MEMORANDUM. Scientific and technical findings that are preliminary or of specialized interest, e.g., quick release reports, working papers, and bibliographies that contain minimal annotation. Does not contain extensive analysis.

- CONTRACTOR REPORT. Scientific and technical findings by NASA-sponsored contractors and grantees.
- CONFERENCE PUBLICATION. Collected papers from scientific and technical conferences, symposia, seminars, or other meetings sponsored or cosponsored by NASA.

- SPECIAL PUBLICATION. Scientific, technical, or historical information from NASA programs, projects, and missions, often concerned with subjects having substantial public interest.

- TECHNICAL TRANSLATION. Englishlanguage translations of foreign scientific and technical material pertinent to NASA's mission.

Specialized services that complement the STI Program Office's diverse offerings include creating custom thesauri, building customized data bases, organizing and publishing research results ... even providing videos.

For more information about the NASA STI Program Office, see the following:

- Access the NASA STI Program Home Page at http://www.sti.nasa.gov

- E-mail your question via the Internet to help@sti.nasa.gov

- Fax your question to the NASA Access Help Desk at (301) 621-0134

- Telephone the NASA Access Help Desk at (301) 621-0390

- Write to:

NASA Access Help Desk

NASA Center for AeroSpace Information 7121 Standard Drive

Hanover, MD 21076 
NASA/TM-2000-209925

\section{The Effect of Stress and TiC Coated Balls on Lifetime of a Perfluoropolyalkylether Using a Vacuum Rolling Contact Tribometer}

William R. Jones, Jr., and Stephen V. Pepper

Glenn Research Center, Cleveland, Ohio

Mark J. Jansen and QuynhGiao Nguyen

AYT Corporation, Brook Park, Ohio

Donald R. Wheeler

Glenn Research Center, Cleveland, Ohio

Achim Schröer

Centre Suisse d'Electronique et de Microtechnique SA, Neuchatel, Switzerland

Prepared for the

Joint Tribology Conference

cosponsored by the Society of Tribologists and Lubrication Engineers and

the American Society of Mechanical Engineers

Seattle, Washington, October 1-4, 2000

National Aeronautics and

Space Administration

Glenn Research Center 
Available from

NASA Center for Aerospace Information

7121 Standard Drive

National Technical Information Service 5285 Port Royal Road Springfield, VA 22100

Hanover, MD 21076

Price Code: A03

Price Code: A03 


\title{
The Effect of Stress and TiC Coated Balls on Lifetime of a Perfluoropolyalkylether Using a Vacuum Rolling Contact Tribometer
}

\author{
William R. Jones, Jr. and Stephen V. Pepper \\ National Aeronautics and Space Administration \\ Glenn Research Center \\ Cleveland, $\mathrm{OH} 44135$ \\ Mark J. Jansen and QuynhGiao Nguyen \\ AYT Corporation \\ Brook Park, OH 44142 \\ Donald R. Wheeler \\ National Aeronautics and Space Administration \\ Glenn Research Center \\ Cleveland, $\mathrm{OH} 44135$ \\ and \\ Achim Schröer \\ CSEM Centre Suisse d'Electronique et de Microtechnique SA, \\ Neuchatel, Switzerland
}

\begin{abstract}
A vacuum spiral orbit tribometer (SOT) was used to determine the relative lifetimes of a branched perfluoropolyalkylether (PFPAE) on $440 \mathrm{C}$ stainless steel. The effect of varying the mean Hertzian stress $(0.75,1.0,1.5$ and $2.0 \mathrm{GPa})$ and the use of TiC coated balls on lubricant lifetime was studied. Other conditions included: $-100 \mathrm{rpm}, ~-50 \mu \mathrm{g}$ of lubricant, an initial vacuum level of $<1.3 \times 10^{-6} \mathrm{~Pa}$ $\left(<1.0 \times 10^{-8} \mathrm{Torr}\right)$, and room temperature $\left(-23^{\circ} \mathrm{C}\right)$. Increasing the mean Hertzian stress from 0.75 to 2.0 $\mathrm{GPa}$ results in an exponential decrease in lubricant lifetime for both material combinations. However, substituting a TiC ball for the $440 \mathrm{C}$ ball quadrupled lifetime at low stress levels $(0.75$ and $1.0 \mathrm{GPa}$ ) and doubled life at higher stresses (1.5 and $2.0 \mathrm{GPa}$ ). The reduced reactivity of the TiC surface with the PFPAE lubricant is considered to be the reason for this enhancement. Decreasing lifetime with increasing stress levels correlated well with energy dissipation calculations.
\end{abstract}

\section{INTRODUCTION}

The materials revolution from improved steels to new-generation, advanced materials, such as technical ceramics, or wear resistant, low friction coatings, made its introduction into ball bearing technology several years ago. Today, much has been published on the properties and advantages of hybrid bearings (steel races and ceramic essentially $\mathrm{Si}_{3} \mathrm{~N}_{4}$-balls), used on a regular basis in machine tool applications. Pseudohybrid bearings (steel races and ceramic coated essentially TiC-steel-balls) are state-ofthe-art in many aerospace applications; e.g., inertial navigation instruments and space mechanisms. The properties of TiC coated balls (1) to (3) and their performance in rolling contacts have been reported (4), (5).

TiC coated balls have important features which make them a favorable compromise to conventional and hybrid bearings. TiC balls have the same bulk properties as steel balls (i.e., elasticity, thermal expansion, and density) and therefore do not influence the bearing load capacity and stiffness. In addition, solid preloaded, pseudo-hybrid bearings allow more thermal excursions than hybrid bearings. TiC coated balls have similar surface properties as ceramic balls (i.e., chemical inertness, hardness, low friction, wear resistance, and smoothness) and therefore do influence the surface-lubricant reactions during asperity collisions (6).

Because of the improved surface roughness of TiC coated balls, less asperity interactions occur. When interactions do occur, there is a strongly 
decreased tendency for micro-welding, accompanied by negligible material transfer and surface roughening. The raceway surface deterioration in a pseudo-hybrid bearing was found to be much less than for conventional, all-steel bearings (7).

Initially, TiC coated balls were developed to operate in bearings for space mechanisms without lubrication. Although some of these dry bearings are still used in space, the great majority of applications utilize conventional liquid lubricants and greases. For example, the GOES weather satellite program uses TiC coated balls for all of their perfluoropolyalkylether (PFPAE) lubricated bearings.

A series of branched polymeric PFPAEs are detailed in Reference (B). All unformulated PFPAEs function in a corrosive wear mode during mixed or boundary lubrication (9). This wear mode, which results in the formation of surface fluorides, allows lubricated contacts to survive without catastrophic failure. However, these surface fluorides accelerate the destruction of the PFPAE, eventually resulting in contact failure as the lubricant is totally consumed. It has been shown by Carre (10) that the substitution of solid ceramic balls (silicon nitride) or TiN coatings can extend the performance of PFPAEs by a factor of 5 to 10 times. This same study showed a decrease in bearing lifetime with increasing Hertzian stress.

The objective of this work was twofold. First, the effect of a range of mean Hertzian stress $(0.75$, $1.0,1.5$, and $2.0 \mathrm{GPa}$ ) on lubricant lifetime of a branched perfluoropolyalkylether (143AC) with $440 \mathrm{C}$ steel was studied using a vacuum Spiral Orbit tribometer (SOT). Secondly, the effect of substituting a TiC coated steel ball under the same conditions was determined. Other conditions included: $\sim 100 \mathrm{rpm}, \sim 50 \mu \mathrm{g}$ of lubricant, room temperature $\left(-23{ }^{\circ} \mathrm{C}\right)$, and an initial vacuum of $<1.33 \times 10^{-6} \mathrm{~Pa}\left(<1.0 \times 10^{-8}\right.$ Torr $)$.

\section{EXPERIMENTAL}

The NASA Spiral Orbit rolling contact tribometer (SOT) was used for all tests. This device (Figure 1) is essentially a thrust bearing using a single bearing ball and two flat races having contact stresses and ball motions similar to those in an angular contact ball bearing. This tribometer is fully described in Reference (11). Other details appear in References (12) and (13).

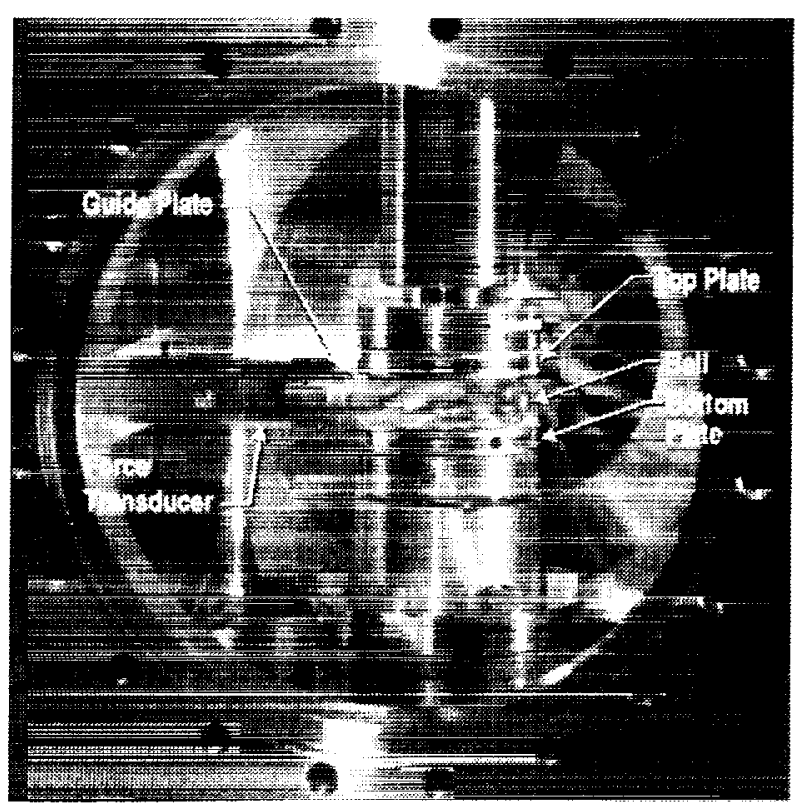

Figure 1 - The spiral orbit tribometer (SOT).

Balls and plates are cleaned with a series of solvents and a final cleaning using UV-ozone. The ball is then lubricated with approximately 50 micrograms of the PFPAE (143 AC). This is accomplished by placing droplets of a Freon 113 solution of the PFPAE on a rotating ball. As the solvent evaporates, a lubricant film is deposited. The final lubricant charge is determined by weighing the ball before and after deposition using a microgram balance. The plates are initially unlubricated.

The ball is placed between the plates and loaded to the desired stress. When the chamber pressure level reaches $1.3 \times 10^{-6} \mathrm{~Pa}\left(1.0 \times 10^{-8}\right.$ Torr $)$, the test is automatically started. As the upper plate rotates $(100 \mathrm{rpm})$, the ball is driven in a spiral orbit. At this speed, the system operates in the boundary lubrication regime. A transducer in the mounting arm of the guide plate (Figure 1) measures the force required to nudge the ball back to the starting point of the original orbit. As the lubricant is consumed during the rolling process, this force increases until at some predetermined friction coefficient ( 0.38 for these tests) the test is automatically terminated. A typical coefficient of friction as a function of test time appears in Figure 2. 


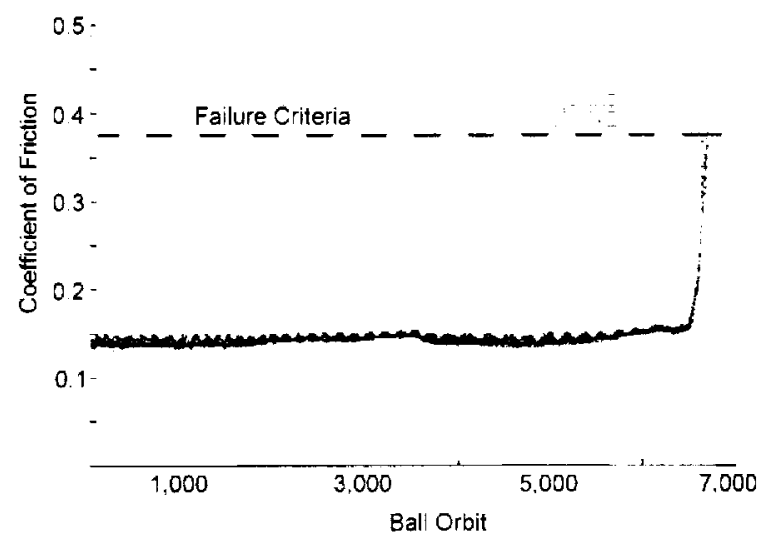

Figure 2 - Typical friction trace as a function of ball orbits for a SOT test ( $1.5 \mathrm{GPa}$, TiC coated ball)

In addition, other parameters (contact resistance and system pressure) are monitored during the test. An example of system pressure as a function of test duration for the test from Figure 2 appears in Figure 3.

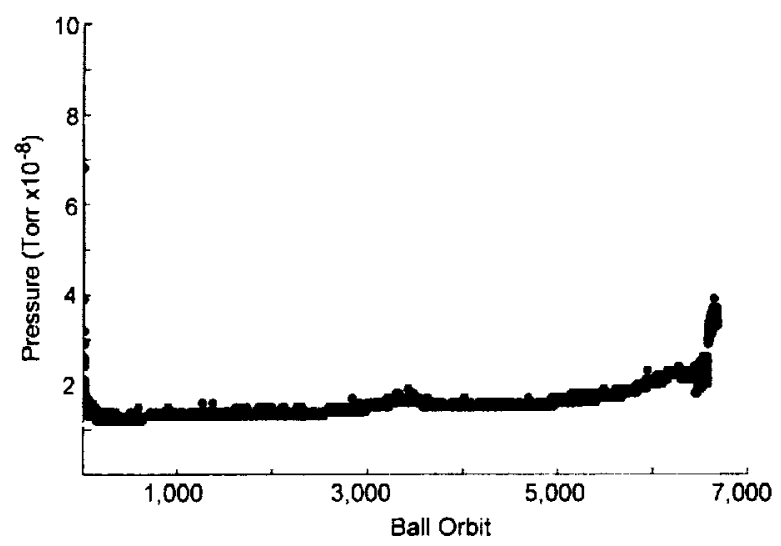

Flgure 3 - Typical pressure data as a function of ball orbits for a SOT test ( $1.5 \mathrm{GPa}, \mathrm{TiC}$ ball).

\section{RESULTS}

\section{LUBRICANT LIFETIMES}

The effect of mean Hertzian contact stress on lubricant lifetime is shown in Figure 4. Each condition represents from four to eight tests, except for the $2.0 \mathrm{GPa} \mathrm{TiC}$ condition that was only run twice. Normalized lubricant lifetime as the number of orbits per microgram of lubricant is plotted for four different mean stress levels $(0.75$,
1.0, 1.5, and $2.0 \mathrm{GPa}$ ). In addition, data for TiC coated balls under the same conditions are shown.

A decrease in lubricant lifetime that is apparently exponential as a function of contact stress is evident for both material combinations. However, it is also clear that the substitution of a TiC coated ball enhances lubricant lifetime at all conditions. Life is quadrupled at 0.75 and $1.0 \mathrm{GPa}$ and doubled at 1.5 and $2.0 \mathrm{GPa}$.

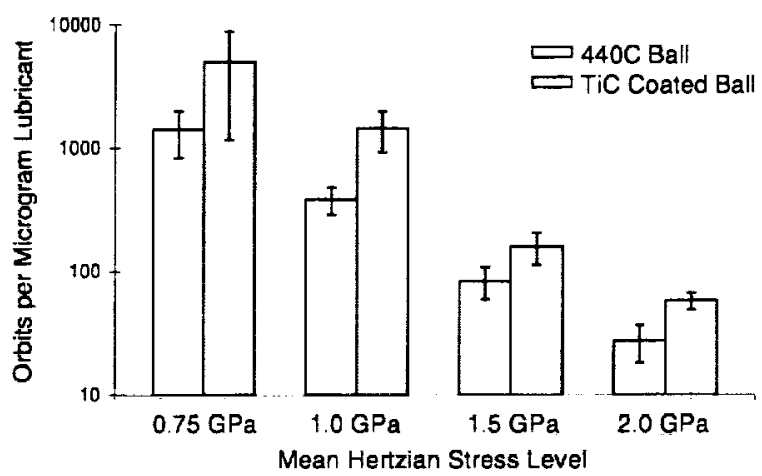

Figure 4 - Effect of Hertzian stress on lubricant lifetime using $440 \mathrm{C}$ and $\mathrm{TiC}$ coated bearing balls.

\section{SURFACE CHEMICAL ANALYSIS}

Several balls from selected tests were analyzed at test conclusion with $\mathrm{X}$-ray photoelectron spectroscopy (XPS) and $\mu$-Fourier Transform Infrared Spectroscopy ( $\mu$-FTIR). In addition, a $440 \mathrm{C}$ ball run to 2,200 orbits at $1.5 \mathrm{GPa}$ ( half-life) was also analyzed. Minimal amount of metallic fluoride is seen on the half-life test. In contrast, a large amount of metallic fluoride is evident on the specimen run to test conclusion. Surface fluoride was evident on all balls run to test conclusion. However, the amount of fluoride was quite variable. There was no correlation with stress level.

\section{DISCUSSION}

The Hertzian contact region in a rolling element bearing is essentially a microchemical reactor. In this high-pressure region, the lubricant can undergo chemical reactions due to the asperity interactions and catalytic effects of the surfaces. For PFPAE lubricants, these reactions include: chain scission, cross-linking, unzipping, 
defluorination, and eventual conversion into a graphitic amorphous carbon (14).

In the spiral orbit tribometer, most of the orbit represents the normal rolling with pivot (15) that is seen in instrument bearings. When the spiraling ball contacts the guide plate, it is forced back into the original (smaller radius) orbit. During this process, termed the scrub, pure sliding takes place between the ball and upper plate. The length of the scrub is typically about $4 \mathrm{~mm}$. The force generated during the scrub allows the coefficient of friction to be determined.

\section{ENERGY DISSIPATION}

Energy is dissipated in the Hertzian contact as a result of pivoting during the rolling portion of the orbit and in the scrub, at the pure sliding contact at the upper plate. This energy dissipation is the driving force for lubricant degradation. It is obvious that for PFPAEs, in general, degradation is initiated immediately during the rolling process because there is an immediate rise in system pressure and an appearance of PFPAE fragments in the residual gas analysis. In addition, the intensity of fluorocarbon fragment emission increases during the scrub.

A detailed analysis of energy loss during rolling/sliding in a 3 -ball system appears in Reference (11) and can be applied to the present one ball operation. The total energy dissipation per unit time is termed "severity." The severity can be integrated over the time of a complete orbit. Since the lubricant is only on the ball (at least initially), the fraction of the ball's surface rolled upon per orbit must also be considered. Then, assuming that lubricant lifetime is inversely proportional to the energy dissipated during an orbit, a relative lifetime can be calculated at different stresses. This data, plotted as a function of load, appears in Figure 5. All lifetime data is normalized to the highest load. Experimental data for both $440 \mathrm{C}$ and TiC coated balls appear as well. There is good agreement between the calculated and experimental results. Thus, the load dependence on lubricant lifetime may be understood on the basis of lubricant degradation by frictional energy dissipation at the ball/plate contacts.

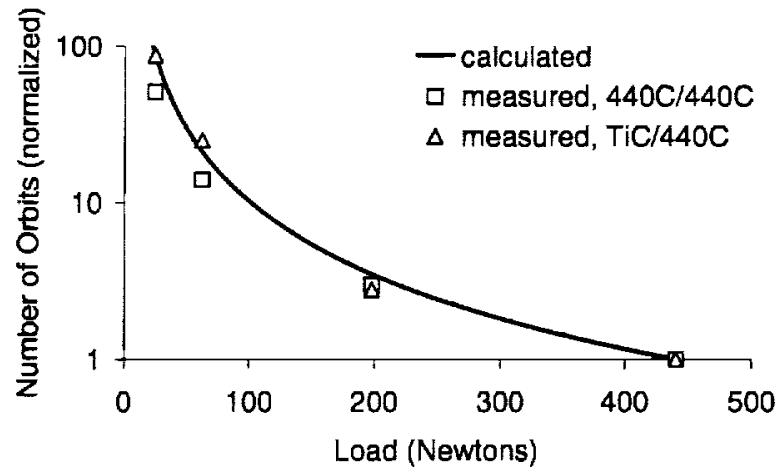

Figure 5 - Relative lifetime of a PFPAE (143AC) as a function of load in the spiral orbit tribometer.

\section{RATE OF LUBRICANT DEGRADATION}

As stated earlier, lubricant degradation immediately commences as the ball starts to roll and increases by an order of magnitude during the scrub. By studying the friction force and pressure curves during a test, it appears that this degradation is relatively constant until late into the test. For the branched PFPAE, there is a rise in system pressure at about 80 to 90 percent of life followed by an abrupt increase in friction, which results in test termination. $\mu-F T I R$ analysis of the balls indicates very little lubricant remaining and what is left is severely degraded. XPS analysis indicates the formation of metallic surface fluoride.

Zehe and Faut (16) have shown that reactions of a linear PFPAE fluid and iron oxide powder involves a two-stage process. The first stage is the slow catalytic decomposition of the PFPAE, which generates highly reactive fluorocarbon species that attack and eventually convert the oxide to fluoride. The second stage involves the rapid degradation of the PFPAE by the much more catalytic iron fluoride. This appears to be the process involved here.

\section{TIC VERSUS $440 \mathrm{C}$}

Shogrin et al. (17) performed ball on disc pure sliding experiments with $440 \mathrm{C}$ specimens implanted with various species (disc only) and lubricated with PFPAE (143 AC). Lubricated lifetimes were enhanced by implantation with either $\mathrm{Ti}$ or a combination of $\mathrm{Ti}+\mathrm{C}$. It was postulated that 
these implanted species produced a passivating layer that reduced the catalytic degradation of the lubricant, thus increasing lifetime. The life enhancement using TiC coated balls in the current study is considered to be a similar phenomenon.

\section{CONCLUSIONS}

For space bearing applications where perfluoropolyalkylether (PFPAE) lubricants are chosen, the use of TiC coated steel balls is beneficial.

The lifetimes of PFPAE lubricants used for longterm space applications will be adversely affected at high Hertzian contact stresses.

The life enhancement gained by using $\mathrm{TiC}$ coated balls instead of $440 \mathrm{C}$ steel balls decreases with increasing stress level.

Relative lubricant lifetime can be correlated with the severity of energy dissipation in the rolling/sliding contacts.

\section{REFERENCES}

1. Boving, H. J. and Hintermann, H. E., "Properties and Performance of CVD TiC-coated Ball Bearing Components," Thin Solid Films, 153, pp. 253-266 (1987).

2. Hanson, R. H., "The Adhesion and Deformation Properties of CVD TiC Coated Bearing Balls under Heavy Load," MRS Symp. Proc., 140, pp. 477-482 (1989).

3. Wong, $\mathrm{S}$. and Cababe, H., "Analysis of TiC Coated Balls," Proc. Inter. Rolling Element Bearing Symp., DoD, REBG, Orlando, FL, April 28-30 (1997).

4. McKee, F. B., "Silicon Nitride and TiC coated Balls in Heavily Loaded Oscillating Bearings," Proc. Bearing Symp., DoD, RBWG, Orlando, FL, April 812 (1991).

5. Walker, R. W., Boving, H. J., Price, R. and Kingsbury, E. P., "Ceramic Coatings as Wear Inhibitors in Slow-Rolling Contact," Proc. ICMCTF, San Diego, CA, April 19-23 (1993).
6. Gill, S., Price, W. B., Rowntree, R. A., Boving, H. J. and Hintermann, H. E., "In-Vacuum Performance of Fomblin Z25-Lubricated 52100 Steel Bearings with TiC-Coated Balls," Proc. Fifth European Space Mech. And Tribology Symp., ESA SP-334, April (1993)

7. Boving, H. J., Fluehmann, F., Schaible, F. and Kleinbard, M., "TiC and Steel Ball Wear Evaluations and Comparisons," Proc. Inter. Rolling Element Bearing Symp., REBG, Orlando, FL, April 28-30 (1997).

8. Gumprecht, W. H., "PR-143-A New Class of HighTemperature Fluids," ASLE Trans., 9, pp. 24-30 (1966).

9. Jones, W. R., Jr., 'Properties of Perfluoropolyethers for Space Applications," STLE Trans., 38, pp. 557564 (1995).

10. Carré, D. J., "The Use of Solid Ceramic and Ceramic Hard-Coated Components to Prolong the Performance of Perfluoropolyalkylether Lubricants," Surface and Coating Tech., 43/44, pp. 609-617 (1990).

11. Pepper, S. V., Kingsbury, E. and Ebihara, B. T., "A Rolling Element Tribometer for the Study of Liquid Lubricants in Vacuum," NASA TP-3629, October 1996.

12. Kingsbury, E., "Evaluation of the NASA Ball on Plate Tribometer as an Angular Contact Ball Bearing," Proc. Inter. Rolling Element Bearing Symp., REBG, Orlando, FL, April 28-30 (1997).

13. Pepper, S. V. and Kingsbury, E., "Destruction of Fomblin Z-25 by Different Bearing Metals," Proc. Inter. Rolling Element Bearing Symp., REBG, Orlando, FL, April 28-30 (1997).

14. Herrera-Fierro, P., Shogrin, B. and Jones, W. R., Jr., "Spectroscopic Analysis of Perfluoropolyether Lubricant During Boundary Lubrication," NASA TM-107299, Sept. 1996.

15. Kingsbury, E., "Pivoting and Slip in an Angular Contact Bearing," ASLE Trans., 27, pp. 259-262 (1984).

16. Zehe, M. J. and Faut, O. D., "Acidic Attack of Perfluorinated Alkyl Ether Lubricant Molecules by Metal Oxide Surfaces," STLE Trans., 33, pp. 634$640(1990)$

17. Shogrin, B., Jones, W. R., Jr., Wilbur, P. J., Herrera-Fierro, P. and Williamson, D. L., "The Effects of Ion Implantation on the Tribology of Perfluoropolyether Lubricated $440 \mathrm{C}$ Stainless Steel Couples," Trib. Trans. 39, 3, pp. 507-516 (1996). 
Public reporting burden for this collection of information is estimated to average 1 hour per response, including the time for reviewing instructions, searching existing data sources, gathering and maintaining the data needed, and completing and reviewing the collection of information. Send comments regarding this burden estimate or any other aspect of this collection of intormation, including suggestions for reducing this burden, to Washington Headquarters Services, Directorate for information Operations and Reports, 1215 Jefferson Davis Highway, Suite 1204, Arlington, VA 22202-4302, and to the Office of Management and Budget, Paperwork Reduction Project (0704-0188), Washington, DC 20503.

\begin{tabular}{|l|c|c|}
\hline 1. AGENCY USE ONLY (Leave blank) & $\begin{array}{c}\text { 2. REPOAT DATE } \\
\text { March } 2000\end{array}$ & $\begin{array}{c}\text { 3. REPORT TYPE AND DATES COVERED } \\
\text { Technical Memorandum }\end{array}$ \\
\hline 4. TITLE AND SUBTITLE & $\begin{array}{r}\text { 5. FUNDING NUMBERS } \\
\hline\end{array}$
\end{tabular}

The Effect of Stress and TiC Coated Balls on Lifetime of a

Perfluoropolyalkylether Using a Vacuum Rolling Contact Tribometer

6. AUTHOR(S)

WU $-251-30-2 E-00$

William R. Jones, Jr., Stephen V. Pepper, Mark J. Jansen, QuynhGiao Nguyen, Donald R. Wheeler, and Achim Schröer

7. PERFORMING ORGANIZATION NAME(S) AND ADDRESS(ES)

National Aeronautics and Space Administration

John H. Glenn Research Center at Lewis Field

Cleveland, Ohio 44135-3191

8. PERFOAMING ORGANIZATION

REPORT NUMBER

E-12164

9. SPONSORING/MONITORING AGENCY NAME(S) AND ADDRESS(ES)

10. SPONSORINGMONITORING

National Aeronautics and Space Administration

Washington, DC 20546-0001 AGENCY REPORT NUMBER

NASA TM-2000-209925

\section{SUPPLEMENTARY NOTES}

Prepared for the Joint Tribology Conference cosponsored by the Society of Tribologists and Lubrication Engineers and the American Society of Mechanical Engineers, Seattle, Washington, October 1-4, 2000. William R. Jones, Jr., Stephen V. Pepper, and Donald R. Wheeler, NASA Glenn Research Center; Mark J. Jansen and QuynhGiao Nguyen, AYT Corporation, 2001 Aerospace Parkway, Brook Park, Ohio 44142; and Achim Schröer, Centre Suisse d'Electronique et de Microtechnique SA, Rue Jaquet-Droz 1, CH-2007, Neuchatel, Switzerland, Responsible person, William. R. Jones, Jr., organization code 5140, (216) 433-6051.

12a. DISTRIBUTIONAVAILABILITY STATEMENT 12b. DISTRIBUTION CODE

Unclassified - Unlimited

Subject Category: 27

Distribution: Nonstandard

This publication is available from the NASA Center for AeroSpace Information, (301) 62f-0390.

13. ABSTRACT (Maximum 200 words)

A vacuum spiral orbit tribometer (SOT) was used to determine the relative lifetimes of a branched perfluoropolyalkylether (PFPAE) on $440 \mathrm{C}$ stainless steel. The effect of varying the mean Hertzian stress $(0.75,1.0,1.5$ and $2.0 \mathrm{GPa})$ and the use of TiC coated balls on lubricant lifetime was studied. Other conditions included: $\sim 100 \mathrm{rpm}, \sim 50 \mu \mathrm{g}$ of lubricant, an initial vacuum level of $<1.3 \times 10^{-6} \mathrm{~Pa}\left(<1.0 \times 10^{-8} \mathrm{Torr}\right)$, and room temperature $\left(\sim 23^{\circ} \mathrm{C}\right)$. Increasing the mean Hertzian stress from 0.75 to $2.0 \mathrm{GPa}$ results in an exponential decrease in lubricant lifetime for both material combinations. However, substituting a $\mathrm{TiC}$ ball for the $440 \mathrm{C}$ ball quadrupled lifetime at low stress levels $(0.75$ and $1.0 \mathrm{GPa})$ and doubled life at higher stresses $(1.5$ and $2.0 \mathrm{GPa}$ ). The reduced reactivity of the TiC surface with the PFPAE lubricant is considered to be the reason for this enhancement. Decreasing lifetime with increasing stress levels correlated well with energy dissipation calculations.

14. SUBJECT TERMS

15. NUMBER OF PAGES

Space tribology

16. PAICE CODE

\section{SECURITY CLASSIFICATION OF REPORT \\ Unclassified}

18. SECURITY CLASSIFICATION
OF THIS PAGE
Unclassified

Unclassified
19. SECURITY CLASSIFICATION OF ABSTRACT Unclassified 